\title{
Carbon Leakage Versus Policy Diffusion: The Perils and Promise of Subglobal Climate Action Daniel A. Farber*
}

\begin{abstract}
Climate change is a global problem that will ultimately require a concerted global response. Policy analysts, however, are divided about whether individual jurisdictions and groups of jurisdictions should take the initiative in the meantime. This Article argues in favor of subglobal efforts, both for their direct effects on emissions and their role as steps toward global cooperation. Some analysts argue that subglobal efforts are futile because of the problem of carbon leakage. More careful analyses, bowever, bave shown that leakage is unlikely to pose a severe threat to the effectiveness of well-designed subglobal mitigation efforts. Poligy design can manage leakage levels and prevent them from frustrating mitigation efforts. Moreover, mitigation efforts in one set of jurisdictions seem more likely to increase rather than decrease the likelibood of mitigation elsewbere. By building confidence among the key actors, subglobal actions can belp pave the way for broader international cooperation. Indeed, without prior subglobal efforts, it is difficult to imagine a successful global agreement. Subglobal efforts are needed as confidence-building measures, providing a basis for mutual cooperation. Subglobal efforts are also needed to experiment with and improve policy instruments that can then be launched at the global level. In short, subglobal efforts are not only desirable but indispensable.
\end{abstract}

\section{Table of Contents}

I. Introduction. 360

II. Subglobal Climate Efforts and Motives.

Sho Sato Professor of Law, University of California, Berkeley. I would like to thank Juscelino Colares, Andrew Guzman, Katerina Linos, and Elizabeth Wilson for helpful comments on previous drafts. I also benefited from discussions at The University of Chicago Law School's Conference on Climate Justice and at a workshop at the 2012 Berkeley faculty retreat. 


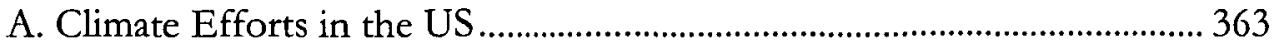

B. Other Developed Country Actions ............................................................... 365

C. Developing Countries: The Case of China ………….................................... 367

III. Leakage from Subglobal Efforts ....................................................................... 368

IV. Strategic Benefits and Costs of Subglobal Action ......................................... 372

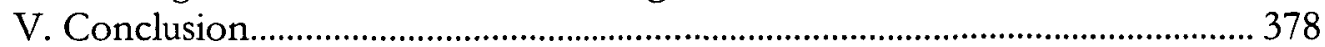

\section{INTRODUCTION}

Climate change is a global problem that will ultimately require a concerted global response. ${ }^{1}$ Policy analysts are divided, however, about whether individual jurisdictions and groups of jurisdictions should take the initiative in the meantime. This Article argues in favor of subglobal efforts, both for their direct effects on emissions and their role as steps toward global cooperation. But the issues are not simple.

Critics argue that subglobal action is futile if not counterproductive. According to Eric A. Posner and David Weisbach, "local initiatives address the climate problem in an extremely inefficient way, and probably not at all." In their view, "[r]aising the cost of energy production or consumption in one city or state will predictably cause people and businesses to migrate to other states, where they can continue to pollute."3 Thus, they argue, subglobal climate action is symbolic rather substantive, meant to persuade the public that something is

1 See, for example, Kirsten H. Engel and Scott R. Saleska, Subglobal Regulation of the Global Commons: The Case of Climate Change, 32 Ecol L Q 183, 187 (2005) (endorsing the need for global action by advocates of state climate regulation). Without global agreement, it may be impossible even for a large coalition of nations to achieve a goal of limiting climate change to $2^{\circ} \mathrm{C}$. See Henry D. Jacoby, et al, Sharing the Burden of GHG Reductions, Discussion Paper 08-09*13 (Harvard Project on International Climate Agreements 2008), online at http://belfercenter.ksg.harvard.edu/ files/JacobylWeb2.pdf (visited Oct 17, 2012). This does not necessarily mean that less ambitious climate goals would be unattainable by coalitions. But even taking the ultimate need for global cooperation as a given, there remains the question of what interim steps would be constructive.

2 Eric A. Posner and David Weisbach, Climate Change Justice 69 (Princeton 2010), reviewed by Daniel A. Farber, Climate Justice, 110 Mich L Rev 985 (2012). See also Rachel Brewster, Stepping Stone or Stumbling Block: Incrementalism and National Climate Change Legislation, 28 Yale L \& Poly Rev 245, 246-47 (2009-10); Jonathan B. Wiener, Think Globally, Act Globally: The Limits of Local Climate Policies, 155 U Pa L Rev 1961, 1963 (2006-07) (describing the efforts as "counterproductive").

3 Posner and Weisbach, Climate Cbange Justice at 69 (cited in note 2). Moreover, they write, jurisdictions that display a strong preference for climate action and would suffer from climate change lose bargaining power because they cannot credibly threaten to walk away from negotiations. Id at 194 . The prospect of such a weakened negotiating posture could deter interim mitigation measures. 
being done without paying the costs of genuine mitigation: "Symbols, not substance, have been the order of the day." In short, Posner and Weisbach say, "unilateral actions can have little impact on the problem, and so it makes sense to await a treaty rather than put in place expensive but unhelpful regulations."

This line of argument is supported by the matching principle, which holds that the level of governance should match the scale of the harm being regulated. ${ }^{7}$ In contrast, other writers reject the matching principle and forcefully advocate subglobal action, at least until a global regime is in place. ${ }^{8}$

The dispute about the consequences of subglobal action is related to a normative debate about whether, in the absence of a climate treaty, major sources have a duty to reduce their carbon emissions.' 'The answer to that question may depend partly on an individual's moral framework, but in almost anyone's framework, the consequences of subglobal action will be relevant to assessing its ethical status.

This Article will present the case in favor of subglobal action. Section II will provide a brief update on notable subglobal efforts within the US and elsewhere. ${ }^{10}$ Section III turns to potential forms of carbon leakage that might

$4 \quad$ Id at 60.

5 Id at 59. The modesty of initial subglobal efforts, however, can be seen as part of an iterative process of confidence building rather than a sign of a lack of serious intent.

$6 \quad$ Id at 8.

7 See Henry N. Butler and Jonathan R. Macey, Extermalities and the Matching Principle: The Case for Reallocating Environmental Regulatory Authority, 14 Yale L \& Poly Rev 23, 35 (1996).

8 See Engel and Saleska, 32 Ecol L Q at 187-88, 223 (cited in note 1).

9 See, for example, Joakim Sandberg, "My Emissions Make No Difference": Climate Change and the Argument from Inconsequentialism, 33 Envir Ethics 229 (2011) (exploring the ethical arguments in depth); Posner and Weisbach, Climate Change Justice at 104 (cited in note 2) (questioning "whether people are morally obliged to cut back on greenhouse gas emissions if others are not doing the same"); Daniel Farber, The Case for Climate Compensation: Justice for Climate Change Victims in a Complex World, 2008 Utah L Rev 377 (2008) (arguing contra Posner and Weisbach in favor of a duty to mitigate); Paul G. Harris, ed, China's Responsibility for Climate Cbange: Etbics, Faimess, and Environmental Poligy (Bristol 2011) (arguing that China has a growing responsibility for climate change). The normative case for a duty to mitigate becomes easier if subglobal action can be expected to result in lower global carbon levels or further a global agreement, and more difficult to the extent that the opposite is true. But given the number of possible moral theories that might be invoked, drawing a stronger conclusion is complicated.

10 The motivations behind such efforts are complex. See Peter Christoff and Robyn Eckersley, Comparing State Responses, in John S. Dryzek, Richard B. Norgaard, and David Schlosberg, eds, The Oxford Handbook of Climate Change and Society 431, 444 (Oxford 2011) ("It should be clear from the foregoing analysis that the quest to find a single cause, or even a common set of drivers, to explain climate leaders or climate laggards is a near-futile exercise."). For present purposes, the effects of subglobal efforts are more important than their motivations. Nevertheless, the existence of a wide range of motivations also suggests the possibility of a diverse set of levers that could be 
undermine subglobal efforts. Leakage could include capital flight to higher emitting jurisdictions as well as indirect impacts on emissions through changes in fuel prices. Section III concludes that leakage, while a potential problem, should not eliminate the benefits of properly designed subglobal efforts. Section IV then considers the impact of subglobal mitigation efforts on similar efforts by other jurisdictions. Regulatory spillover effects could result in slacking off in efforts by other jurisdictions, but could also prompt mitigation efforts by others, a form of incremental multilateralism. ${ }^{11}$ On balance, the positive spillover effects of subglobal action are likely to predominate. Section V concludes by stressing the limited downside and important upside potential of subglobal actions to reduce carbon emissions while paving the road for global cooperation.

Skeptics do raise legitimate questions about the utility of subglobal action. Despite the possibility that such actions may cause capital flight or otherwise stimulate increases in emissions by outsiders, however, the weight of the evidence discussed in Section III demonstrates that subglobal actions can mitigate climate change. Under plausible assumptions, incremental subglobal actions also increase the likelihood that other actors, too, will find mitigation attractive, thereby improving the likelihood that a global regime will emerge. Thus, while they have value as symbols and as carbon reductions, subglobal actions also have strategic value in advancing global mitigation efforts. ${ }^{12}$

In Massacbusetts v EP $A,{ }^{13}$ Justice Stevens's opinion for the Court presented a commonsense view of the desirability of incremental, subglobal measures: "A reduction in domestic emissions would slow the pace of global emissions increases, no matter what happens elsewhere." ${ }^{\prime 4}$ That is certainly true in terms of

used by some jurisdictions to help motivate others. This Article assumes that at least countries are more likely to initiate or join a subglobal effort to the extent that (1) benefits are less likely to be undermined by leakage, (2) costs are lower, and (3) the subglobal effort increases the prospects for a later global agreement. These assumptions about the relative likelihood of mitigation efforts seem plausible regardless of one's model for state behavior.

11 For discussion of multilateral incrementalism as a climate strategy, see Rafael Leal-Arcas, Alternative Architecture for Climate Change: Major Economies, 4 Eur J Legal Studies 25, 36-38, 55-56 (2011).

12 In economic terms, the question could be posed as to whether subglobal climate efforts are strategic substitutes or strategic complements. These concepts stem from a seminal paper, Jeremy I. Bulow, John D. Geanakoplos, and Paul D. Klemperer, Multimarket Oligopoly: Strategic Substitutes and Complements, $93 \mathrm{~J}$ Pol Econ 488 (1985). More recent research indicates, however, that the game theoretic formulations of this concept may not produce stable equilibria, a finding that undermines their utility for policy analysis. See Federico Echenique and Aaron Edlin, Mixed Equilibria Are Unstable in Games of Strategic Complements, $118 \mathrm{~J}$ Econ Theory 61 (2004). In any event, while evocative, the analogy to this economics issue will not be pursued in this Article.

13549 US 497 (2007).

14 Id at 526 
the first-order effects. The situation is more complex, however, because secondorder effects can either bolster or counter this primary effect. In the end, however, Justice Stevens was right that such subglobal actions provide the best prospect for progress. Indeed, if countries wait until a global international agreement is reached before taking any action of their own against climate change, it is hard to see how such an agreement could ever be reached.

\section{Subglobal Climate EfForts and Motives}

A comprehensive survey of climate mitigation efforts around the world, or even within various levels of government in the United States, would require a lengthy tome. This section will not attempt such a survey, but it is important to provide some sense of the scope and variety of subglobal efforts. The sample of mitigation efforts discussed in this section provides some concrete context for the more theoretical discussion that follows in Sections III and IV.

\section{A. Climate Efforts in the US}

Subglobal efforts can take place at various levels of government. In the US, state governments have actively engaged with the issue of climate change. ${ }^{15}$ By 2006 , every state had taken steps of some kind to address climate change. ${ }^{16}$ As of 2009, twenty-one states had established goals for greenhouse gas (GHG) emission reductions, and nearly a thousand mayors had endorsed such a goal. ${ }^{17}$ One of the most popular state policies is the adoption of renewable portfolio standards (RPSs), which require that a certain percentage of retail electricity sales be derived from renewable sources. ${ }^{18}$ California's RPS has an especially ambitious 33 percent target by $2020 .^{19}$

15 Regional efforts are described in Eleanor Stein, Regional Initiatives to Reduce Greenhouse Gas Emissions, in Michael B. Gerrard, ed, Global Climate Change and U.S. Law 315 (American Bar Association 2007); David Hodas, State Initiatives, in Gerrard, ed, Global Climate Cbange 343. A survey of state efforts can be found in Pace Law School Center for Environmental Legal Studies, The State Response to Climate Change: 50-State Survey, in Gerrard, ed, Global Climate Change 371.

16 Hodas, State Initiatives at 343 (cited in note 15). See also Edella C. Schlager, Kirsten H. Engel, and Sally Rider, eds, Navigating Climate Change Policy: The Opportunities of Federalism (Arizona 2011) (providing a collection of thoughtful evaluations of this trend).

17 Michael Burger, Emponering Local Autonomy and Encouraging Experimentation in Climate Change Governance: The Case for a Layered Regime, 39 Envir L Rptr 11161, 11163 (2009).

18 Michael B. Gerrard, Introduction, in Gerrard, ed, Climate Change 1, 22 (cited in note 15).

19 California Air Resources Board, RPS Program Overview, online at http://www.cpuc.ca .gov/PUC/energy/Renewables/overview (visited Oct 17, 2012). 
In California, efforts focusing specifically on climate change date back to 1988, when AB 4420 called for the first inventory of in-state greenhouse gas emissions. ${ }^{20}$ In 2006, Governor Schwarzenegger signed the California Global Warming Solutions Act of 2006, or AB 32, ${ }^{21}$ which requires California to reduce emissions to the 1990 level by $2020{ }^{22}$ This law generated worldwide attention, including a statement by the British prime minister that its signing represented a "historic day for the rest of the world as well."23 The prime minister and the governor of California also entered into an agreement to share best practices on market-based systems and to cooperate to investigate new technologies; similar agreements now exist between California and states and provinces in Australia and Canada. ${ }^{24}$

California's effort cannot be characterized as merely symbolic. In implementing $\mathrm{AB}$ 32, the California Air Resources Board (CARB) first developed "discrete early action greenhouse gas emission reduction measures," 25 some of which focus on reducing emissions of high global warming potential (GWP) gases. Another important early action was a low-carbon fuel standard to reduce the GHG intensity of transportation fuels by 10 percent by $2020 .{ }^{26} \mathrm{~A}$ recently adopted cap-and-trade program sets a declining, statewide cap on GHG emissions and covers about 600 industrial facilities. ${ }^{27}$

States have also combined efforts in regional programs, ${ }^{28}$ including the Northeast Regional Greenhouse Gas Initiative (RGGI) as well as initiatives in New England, the Great Plains, the Southwest, and the West Coast. ${ }^{29}$ RGGI,

20 State Energy Resources Conservation and Development Commission, 1988 Cal Assembly Bill 4420, ch 1506.

212006 Cal Assembly Bill 32, ch 488, codified at Cal Health \& Safety Code $\$ 38500$ et seq.

22 Erwin Chemerinsky, et al, Califormia, Climate Change, and the Constitution, 37 Envir L Rptr 10653, 10653 (2007).

23 Id at 10654.

24 Id at 10659.

25 Cal Health \& Safety Code $₫ 38560.5(\mathrm{a}-\mathrm{b})$.

26 Governor Arnold Schwarzenegger, Executive Order S-01-07 (Jan 18, 2007), online at http://www.arb.ca.gov/fuels/lcfs/eos0107.pdf (visited Oct 17, 2012).

27 See generally California Environmental Protection Agency Air Resources Board, ARB Emissions Trading Program Overview, online at http://www.arb.ca.gov/newsrel/2010/capandtrade.pdf (visited Oct 17, 2012).

28 See Kirsten $\mathrm{H}$. Engel, Mitigating Global Climate Change in the United States: A Regional Approach, 14 NYU Envir L J 54, 65 (2005-06).

29 Stein, Regional Initiatives at 316 (cited in note 15). For more on systems other than the Regional Greenhouse Gas Initiative, see id at 326-31. 
which currently comprises nine states,$^{30}$ created a multistate trading system for power plant emissions with the goal of achieving a 10 percent reduction by $2018 .^{31}$

Action has also begun at the federal level, despite a lack of action from Congress. In response to the Supreme Court's decision in Massacbusetts v EPA, the EPA made a formal finding that greenhouse gases endanger human health and safety. ${ }^{32}$ With this finding as a foundation, the EPA has developed regulations to reduce greenhouse gases. ${ }^{33}$ These measures, which were recently upheld by the DC Circuit, ${ }^{34}$ will result in measurable reductions in US emissions. For instance, EPA regulation of power plants could "capture a potential reduction of 5 to 10 percent in GHG emissions from coal-as much as about 3 percent of total US emissions." ${ }^{35}$ In general, "it appears a regulatory approach could achieve emissions reductions through mitigation in the domestic economy of up to 10 percent, relative to 2005 levels," which "would be comparable to domestic reductions that would have been achieved under the legislative capand-trade proposal. ${ }^{\text {,36 }}$

\section{B. Other Developed Country Actions}

The European Union has also been an energetic subglobal actor. The EU began operating the world's first mandatory carbon dioxide emissions trading

30 Regional Greenhouse Gas Initiative (RGGI), online at http://www.rggi.org/ (visited Oct 17, 2012) (an initiative of the Northeast and Mid-Atlantic States of the US).

31 See RGGI, Program Design, online at http://www.rggi.org/design (visited Oct 17, 2012).

32 See United States Environmental Protection Agency, Endangerment and Cause or Contribute Findings for Greenhouse Gases under Section 202(a) of the Clean Air Act, online at http://www.epa.gov/ climatechange/endangerment (visited Oct 17, 2012).

33 The regulations are described on the EPA website. See US Environmental Protection Agency, Regulatory Initiatives, online at http://www.epa.gov/climatechange/initiatives/index.html (visited Oct 17, 2012).

34 Coalition for Responsible Regulation, Inc v Environmental Protection Agency, 684 F3d 102, 113 (DC Cir 2012).

35 Dallas Burtraw, Arthur G. Fraas, and Nathan D. Richardson, Greenhouse Gas Regulation Under the Clean Air Act: A Guide for Economists, Discussion Paper 11-08*14 (Resources for the Future 2011), online at http://ssm.com/abstract $=1759571$ (visited Oct 17, 2012).

36 Id at *16. A more recent study indicates that EPA measures combined with state measures and shifts in fossil fuel markets will allow the US to meet its Copenhagen commitment to reduce emissions. See Dallas Burtraw and Matthew Woerman, US Status on Climate Change Mitigation, Discussion Paper 12-48 (Resources for the Future 2012), online at http://www.rff.org/Publications/Pages/PublicationDetails.aspx?PublicationID=22073 (visited Oct 25, 2012). 
scheme in January $2005 .{ }^{37}$ For internal political reasons, the EU distributed to "its then 15 member countries its internationally agreed target, ranging (relative to the 1990 base period) from cuts of 28 percent (Luxembourg) to an allowed increase of 27 percent (Portugal)." ${ }^{38}$ EU members then established their own trading programs, using a variety of schemes to allocate permits to their industries. ${ }^{39}$ The program got off to a rocky start. ${ }^{40}$ Allowance prices have fluctuated from as little as one euro to as many as thirty. ${ }^{41} \mathrm{~A}$ third phase, with more ambitious targets and greater use of auctioning, will launch across 2013$21 .^{42}$

Despite its flaws, the European trading system (ETS) has reduced emissions by an estimated fifty to one hundred megatons per year, or 2.5 percent to 5 percent. ${ }^{43}$ The program may also have broader significance. By establishing "a system that will demonstrate the societal decision that GHG emissions shall have a price and to provide the signal of what constitutes appropriate short-term and long-term measures to limit GHG emissions," the European Union "has done more with the ETS, despite all its faults, than any other nation or set of nations." ${ }^{44}$ The sticking points encountered in the first rounds of EU implementation also provide valuable information about program design.

37 European Commission, Emissions Trading System (EU ETS) (Nov 2010), online at http://ec.europa.eu/clima/policies/ets/index_en.htm (visited Oct 17, 2012).

38 Richard N. Cooper, Europe's Emissions Trading System, Discussion Paper 10-40*2 (Harvard Project on International Climate Agreements 2010), online at http://belfercenter.ksg.harvard.edu/ files/CooperETSfinal.pdf (visited Oct 17, 2012).

39 See id at $* 2-5$.

40 For discussion of some of the design defects, see Benjamin K. Sovacool, The Policy Challenges of Tradable Credits: A Critical Review of Eight Markets, 39 Ener Poly 575, 581 (2011).

41 William C. Whitesell, Climate Poligy Foundations: Science and Economics with Lessons from Monetary Regulation 176 (Cambridge 2011). The low initial price resulted from an over-allocation of allowances. See Lesley McAllister, The Overallocation Problem in Cap-and-Trade: Moving Toward Stringengy, 34 Colum J Envir L 395, 397 (2009); Susan J. Kurkowski, Distributing the Right to Pollute in the European Union: Efficiency, Equity, and the Environment, 14 NYU Envir L J 698, 724 (2005-06). For more information on design problems in the EU system, see Denny Ellerman and Paul L. Joskow, The European Union's Emissions Trading System in Perspective 32 (Pew Center Reports 2008), online at http://www.c2es.org/docUploads/EU-ETS-In-Perspective-Report.pdf (visited Oct 17, 2012). For information on the design of the trading system, see European Commission EU Emissions Trading System (cited in note 37 ).

42 See Cooper, Europe's Emissions at 13-14 (cited in note 38).

43 Posner and Weisbach, Climate Change Justice at 68 (cited in note 2).

44 Ellerman and Joskow, Emissions Trading System at 46 (cited in note 41). 
On the other side of the world, Australia has recently launched a combination of an initial carbon tax with a later trading system. ${ }^{45}$ The long-term goal is an 80 percent reduction in greenhouse gases to below 2000 levels by $2050 .^{46}$ Because of a price cap on allowances, the trading system could in effect convert back into an emission charge system if the cap is reached. ${ }^{47}$

Systematic data about national efforts and their effectiveness are not easy to come by. A study by the Australian government of the electricity sector found a range across countries, with Germany and the UK well in the forefront and other countries showing only minor reductions to estimated emissions compared with business as usual. ${ }^{48}$

\section{Developing Countries: The Case of China}

Although developed countries have been most willing to incur costs in mitigating climate change, there has also been some movement among developing countries. By 2010, "China ha[d] persuaded some commentators that it looks forward to a world with lower greenhouse gas emissions and plans to profit by investing in green technology." observers believed it had "not yet shown a serious commitment to reducing greenhouse gas emissions." ${ }^{\text {"50 }}$ But China's Twelfth Five-Year Plan, which covers 2011-15, now includes a 16 percent reduction in energy intensity and an 11.4 percent increase in the share of energy produced by non-fossil energy. ${ }^{51}$ The plan also establishes a longer-term goal of establishing a carbon trading market. ${ }^{52}$

China has also announced that it is "willing to bear the obligations of a legally binding commitment," provided such a commitment is "matched with China's economic development and capabilities based on the principles of

45 See Lisa Caripis, et al, Australia's Carbon Pricing Mechanism, 2 Climate L. 583, 585 (2011).

46 Id.

47 Id at 592. The price cap is AUD $\$ 20$ above the international price of allowances for 2015-16. Id.

48 Productivity Commission, Carbon Emission Policies in Key Economies *75 (Commonwealth of Australia Research Report, Feb 15, 2012), online at http://ssrn.com/abstract $=2006078$ (visited Oct 17, 2012).

49 Posner and Weisbach, Climate Cbange Justice at 60 (cited in note 2).

50 Id.

51 Joanna Lewis, Energy and Climate Goals of China's 12th Five-Year Plan 1 (Pew 2011), online at http://www.c2es.org/docUploads/energy-climate-goals-china-twelfth-five-year-plan.pdf (visited Oct 17, 2012).

52 Id at 2. More recently, China announced a plan to reduce the energy intensity per unit of GDP by 16 percent below 2010 levels by 2015. Michael Standaert, China Releases Plan for Saving Energy, Cutting Emissions, Pledges US\$372 Billion, 36 Intl Envir Rptr (BNA) 826 (2012). 
common but differentiated responsibilities, fair[ness] and environmental integrity." China has made energy goals part of its "cadre system" for promotions, demotions, and pay levels for government officials, which creates a strong incentive for officials to ensure that the goals are met. ${ }^{54}$ Perhaps not coincidentally, China is also beginning to recognize the serious threats that it faces from climate change. ${ }^{55}$ These steps are still inadequate, but they are at least a beginning.

This section has presented merely a sample of the diverse efforts now taking place. These various efforts seem promising, but they may come to naught if the operation of global markets merely transfers those emissions elsewhere. This "leakage" effect is the subject of the next section.

\section{LEAKAGE FROM SUBGLOBAL EFFORTS}

Reducing the use of carbon fuels is an economic act, and it has market consequences that can amplify emissions elsewhere. Leakage can occur in several ways: (1) limits on fossil fuels lower their prices, increasing the demand in other sectors or in other jurisdictions (the price effect); (2) capital investment may move to countries with fewer emissions controls (the capital effect); or (3) other countries may feel less need to abate emissions given that others are doing so (the slack-off effect). ${ }^{56}$ The slack-off effect is mediated by political institutions rather than economic ones and relates to the strategic effects of subglobal climate action, which will be discussed in Section IV. The market-driven price and capital effects will be the focus here. We begin with the price effect.

The price effect has received particular attention in the context of energy conservation measures, where it is commonly called the "rebound effect." rebound effect involves increases in energy use that are paradoxically caused by improved energy efficiency. Because of the rebound effect, it is even

53 China Sets Conditions on Binding Climate Cbange Commitment After 2020, English.news.cn (Dec 6, 2011), online at http://news.xinhuanet.com/english/china/2011-12/06/c_131290906.htm (visited Oct 17, 2012).

54 Alex Wang, The Search for Sustainable Legitimacy: Environmental Law and Bureaucracy in China, 34 Harv Envir L Rev (forthcoming 2013) (on file with the author).

55 See Daniel A. Farber, The Challenge of Climate Change Adaptation: Learning from National Planning Efforts in Britain, China, and the USA, 23 J Envir L (UK) 359, 368 (2011).

56 See Wiener, $155 \mathrm{U} \mathrm{Pa} \mathrm{L} \mathrm{Rev} \mathrm{at} \mathrm{1967-68} \mathrm{(cited} \mathrm{in} \mathrm{note} \mathrm{2);} \mathrm{Cary} \mathrm{Coglianese} \mathrm{and} \mathrm{Jocelyn}$ D'Ambrosio, Poligymaking Under Pressure: The Perils of Incremental Responses to Climate Change, 40 Conn L Rev 1411, 1419-20 (2008).

57 The rebound effect received popular attention in David Owen, The Efficiency Dilemma, New Yorker 78 (Dec 20, 2010). As discussed in the text, the evidence does not support Owen's rather alarmist portrayal, but the issue is genuine. 
theoretically possible that increased energy efficiency could actually lead to greater total consumption of energy. This extreme form of rebound is most likely with regard to industrial uses of energy where increased energy efficiency might raise levels of productivity and economic growth, which would in turn increase the overall use of energy. ${ }^{58}$

The key question regarding the price effect is the size of leakage or rebound. In terms of rebound, the evidence suggests that under most circumstances the magnitude is small to moderate. According to a 2010 review of the economic literature, "there seems to be some evidence for direct rebound under certain conditions like a large unsatisfied demand," but the studies do not support large rebound otherwise. ${ }^{59}$ In developed countries the rebound seems to be below 30 percent, but rebound from efficiency measures in developing countries may be higher because of unmet demand. ${ }^{60}$

The European Union completed a major study of the rebound effect in $2011 .^{61}$ The study estimates direct rebound effects of 5 percent to 12 percent for lighting in developed countries and 15 percent to 20 percent for heating/cooling and appliances. ${ }^{62}$ In general, economy-wide (indirect) rebound seems to be around 10 percent, although it is difficult to estimate. ${ }^{63}$ Policymakers are taking these effects into account. For instance, the UK energy agency "accepts the existence of the direct rebound effects in relevant policy interventions, and officially incorporates "take back" in energy savings from rebound in policy evaluation. ${ }^{64}$

58 Sheetal Gavankar and Roland Geyer, The Rebound Effect: State of the Debate and Implications for Energy Efficiency Research *52-53 (Bren School of Environmental Science and Management, June 26, 2010), online at http://iee.ucsb.edu/files/pdf/Rebound\%20Report\%20for\%20IEE-UCSB.pdf (visited Oct 17, 2012).

59 Id at $* 46$.

60 Id at *61. For some recent evidence against a basic form of rebound (increased use of more efficient products), see Shakeb Afsah and Kendyl Salcito, Non-Conundrum of the Prius Fallacy, $\mathrm{CO} 2$ Scorecard (Mar 26, 2010), online at http://co2scorecard.org/home/researchitem/23 (visited Oct 17, 2012).

61 Dorothy Maxwell, et al, Addressing the Rebound Effect (Final Report, European Commission Directorate-General for the Environment, Apr 26, 2011), online at http://ec.europa.eu/environment/eussd/pdf/rebound_effect_report.pdf (visited Oct 17, 2012).

62 Id at $* 82$.

63 Id at *83.

64 Id at *33. 
Like studies of rebound, studies of leakage have produced varying results. ${ }^{65}$ Estimates in the 1990s ranged from 4 percent to 100 percent. ${ }^{66}$ A 2004 study produced estimates ranging up to 130 percent. ${ }^{67}$ Modeling results for Kyoto indicated leakage rates of 5 percent to 20 percent. ${ }^{68}$ However, leakage rates for particular energy-intensive commodities such as cement and steel could be much higher. ${ }^{69}$

More recent studies seem to produce more modest estimates of leakage, particularly if countermeasures are implemented. A recent study by Resources for the Future (RFF) ${ }^{70}$ found that the highest sectorial leakage level was around 27 percent for petroleum refineries, ${ }^{71}$ with an average rate across industries of around 5 percent with the use of offsetting measures such as output subsidies or trade adjustments. ${ }^{72}$ The RFF study also "estimate[d] that about half of traderelated leakage from the US to non-policy countries is due directly to changes in the volume of trade, and the other half to higher emissions intensities in nonAnnex I trading partners induced by lower world fuel prices."

A team from The University of Chicago and Argonne National Laboratory conducted another recent study ${ }^{74}$ which considered the effect of adopting a carbon tax in the developed countries. They found that such a tax would result in significant global emission reductions and only modest leakage:

In our simulations, a carbon tax in the Kyoto Protocol Annex B nations

(which roughly make up the developed world) will produce only about one-

65 For a concise overview of the leakage literature, see Gabriel Weil, Costs, Contributions, and Climate Change: How Important Are Universally Binding Emissions Commitments?, 23 Georgetown Intl Envir L Rev 319, 319-20 (2011).

66 Wiener, $155 \mathrm{U} \mathrm{Pa} \mathrm{L} \mathrm{Rev} \mathrm{at} 1969$ (cited in note 2).

67 Id at 1970, citing Mustafa H. Babiker, Climate Change Policy, Market Structure, and Carbon Leakage, 65 J Intl Econ 421, 441 (2005).

68 Julia Reinaud, Issues Bebind Competitiveness and Carbon Leakage: Focus on Heaty Industry 33 (International Energy Agency 2008).

69 Id at 36-37.

70 Liwayway Adkins, et al, Carbon Pricing with Output-Based Subsidies: Impact on U.S. Industries over Multiple Time Frames, Discussion Paper 12-27 (Resources for the Future 2012), online at http://ssm.com/abstract $=2099768$ (visited Oct 17, 2012).

71 Id at $* 21$.

72 Id at $* 21-22$.

73 Id at $* 26$.

74 Joshua Elliott, et al, Unilateral Carbon Taxes, Border Tax Adjustments, and Carbon Leakage (University of Chicago Institute for Law and Economics Working Paper 600, Feb 2012), online at http://ssm.com/abstract $=2072696$ (visited Oct 17, 2012). 
third of the reductions of a global tax. Leakage, however, is only a modest part of the story. Our central measures for leakage under a carbon tax in Annex B, defined as the increase in emissions in the non-taxing region as a fraction of emissions reductions in the taxing region, are in the 15-25 percent range. ${ }^{75}$

The study also found that border tax adjustments reduced leakage substantially. ${ }^{76}$

The Intergovernmental Panel on Climate Change (IPCC) has criticized the earlier studies showing high leakage rates for assuming obtuse policy designs:

Results with high leakage therefore reflect conditions in which countries implement policies that lead to most emission savings being obtained by industrial relocation (to areas of lower-cost, and in some cases less efficient, production), rather than in the less mobile sectors (such as power generation, domestic, services, etc.). In practice, most countries have tended to adjust policies to avoid any such outcome (for example through derogation, exemption or protection for such sectors). ${ }^{77}$

In addition, according to the IPCC, other factors may tend to reduce leakage: " [] $\mathrm{n}$ practice, carbon leakage is unlikely to be substantial because transport costs, local market conditions, product variety and incomplete information all favour local production." 78 A recent expert workshop projected relatively modest leakage rates that could be substantially reduced through output-based rebates. ${ }^{79}$

Leakage is countered to the extent that mitigation efforts lead to the generation of new technology that is adopted elsewhere. ${ }^{80}$ The interaction between technological change and impacts on energy prices (the price effect) is somewhat understudied. The scant existing research on technology effects and leakage indicates that the key factors are the elasticity of demand, scarcity of fossil fuels, and substitutability between clean and carbon-based energy. ${ }^{81}$

75 Id at $* 2$.

76 Id at *3.

77 Terry Barker, et al, Mitigation from a Cross-Sectoral Perspective, in Bert Metz, et al, eds, Climate Change 2007: Mitigation of Climate Change: Contribution of Working Group III to the Fourth Assessment Report of the Intergovernmental Panel on Climate Change 619, 666 (Cambridge 2007).

78 Id.

79 Carolyn Fischer, et al, Carbon Policies, Competitiveness, and Emissions Leakage: An International Perspective, Conference Summary (Resources for the Future 2010), online at http://www.rff.org/publications/pages/publicationdetails.aspx?publicationid=21071 (visited Oct 17, 2012).

80 Wiener, $155 \mathrm{U} \mathrm{Pa} \mathrm{L} \mathrm{Rev} \mathrm{at} 1971$ (cited in note 2).

81 See Valentina Bosetti and Enrica De Cian, A Good Opening: The Key to Make the Most of Unilateral Action, Discussion Paper 12-49*5 (Harvard Project on Climate Agreements 2012), online at http://belfercenter.ksg.harvard.edu/files/bosetti-decian_dp2012-49-final.pdf (visited Oct 17, 2012). 
Regulators can also reduce leakage by excluding industries that compete with foreign firms from the trading system, by giving free allowances ${ }^{82}$ or by granting rebates on carbon taxes for exports. ${ }^{83}$ When the regulating jurisdiction is also a major importer, border measures can discourage leakage, with particularly strong effect if producers maintain unified production lines. ${ }^{84} \mathrm{~A}$ recent modeling effort concludes that leakage can also be reduced if other countries anticipate that they will become subject to binding limitations in the future or can sell offset credits to countries that are controlling mitigations. ${ }^{85}$ Expanding the economic size of the coalition engaged in abatement also decreases leakage. ${ }^{86}$ It should also be possible to reduce leakage by taking steps to reduce the supply of fossil fuels, such as restrictions on coal mining or offshore drilling.

The magnitude of leakage is clearly subject to considerable uncertainty. The available evidence seems to point toward two conclusions. The first is simply that leakage is a genuine problem, not a red herring. The second is that leakage is unlikely to be a severe problem for well-designed mitigation measures, particularly if the effort involves a large economy or group of economies.

\section{Strategic Benefits and Costs of Subglobal Action}

Although measuring leakage is not easy, it is even more difficult to determine how mitigation efforts could affect policies in other jurisdictions or the likelihood of international agreement. Political effects of mitigation measures can take many forms. Even purely symbolic efforts may have some positive spillover effects, as Posner and Weisbach explain:

One symbolic action can lead to another, and as more and more people take actions with similar goals, a sense may develop that enough people care about a problem to make substantive government action possible. Support for symbolically potent but environmentally trivial [actions] . . , then, may

82 The EU has adopted this strategy. See European Commission, Carbon Leakage (2012), online at http://ec.europa.eu/clima/policies/ets/leakage/index_en.htm (visited Oct 17, 2012).

83 Reinaud, Issues Behind Competitiveness at 89 (cited in note 68).

84 See Niven Winchester, The Impact of Border Carbon Adjustments Under Alternative Producer Responses, Report $192 * 10$ (MIT Joint Program on the Science and Policy of Global Change, Feb 2011), online at http://globalchange.mit.edu/files/document/MITJPSPGC_Rpt192.pdf (visited Oct 17, 2012). The legality of these measures under trade law is a complex topic that will not be discussed here.

85 Id.

86 Christoph Böhringer, Carolyn Fischer, and Knut Einar Rosendahl, Cost-Effective Unilateral Climate Poligy Design: Size Matters, Discussion Paper 11-34*28 (Resources for the Future 2011), online at http://ssrn.com/abstract $=1977676$ (visited Oct 17, 2012). 
help spread the word about climate change and convince people around the world that enough people care about this problem to make significant emission limits possible. ${ }^{87}$

Predicting how subglobal efforts may impact later negotiations is not a simple matter. The impacts of subglobal mitigation on subsequent negotiations are complex. A binding pre-commitment by one party to reduce emissions sharply could undermine negotiations by reducing the urgency of climate action by other parties and by limiting the bargaining power of the pre-committed party. ${ }^{88}$ This slacking-off effect implies counterintuitively that jurisdictions actually could encourage mitigation efforts elsewhere and improve international coordination by increasing their own emissions. In addition, carbon leakage might increase the economic stakes of other jurisdictions in high carbon activities, which could impede negotiations by making those jurisdictions reluctant to abandon these newly profitable activities. But factors operating in the opposite direction are likely to be more important.

Game theory models provide some insight into the dynamics at work:

This [research] suggests that when countries are willing to increase their emission reduction commitment if others do the same, cooperation is more likely. It also suggests that cooperation would be more likely if an international mechanism were to exist that would allow countries to make a binding conditional commitment. Approaches that discourage "backtracking" are more likely to be successful. ${ }^{89}$

Subglobal mitigation might satisfy these conditions if mitigation by some jurisdictions facilitates mitigation by others, and if partial mitigation makes backsliding less attractive while making it more likely that mitigation efforts will be reciprocated. Under those circumstances, a virtuous cycle could emerge in which emission reduction efforts become contagious and mutually reinforcing. ${ }^{90}$

87 Posner and Weisbach, Climate Change Justice at 60 (cited in note 2). Posner and Weisbach go on to note that symbolic actions could also have a lulling effect if people think they are sufficient to eliminate the problem. Id. Empirical evidence about the extent of any such lulling effect would be very helpful.

88 See Kai A. Konrad and Marcel Thum, Climate Policy Negotiations with Incomplete Information*10-12 (Max Planck Institute for Tax Law and Public Finance Working Paper 2011-19, Dec 2011), online at www.ssrn.com/abstract $=1971638$ (visited Oct 17, 2012).

89 Peter John Wood, Climate Change and Game Theory: A Mathematical Survey *33 (Centre for Climate Economics \& Policy Working Paper 2.10, July 2011), online at http://ssm.com/ abstract $=1883944$ (visited Oct 17, 2012).

90 To be more specific, the hypothesis is that mitigation efforts in one jurisdiction (1) decrease the likelihood that that jurisdiction will later increase emissions and (2) increase the likelihood of mitigation efforts in other jurisdictions. This is a probabilistic effect, so one would expect to see a degree of randomness in outcomes in addition to this basic trend. 
Such a virtuous cycle could take hold if reductions by a subset of emitters are difficult to retract and make it more likely that others will also reduce their emissions. This dynamic can occur if emissions reductions change the economic and political balance in favor of reductions by others. Thus, emissions reductions could promote further mitigation if they increase the economic or political benefits of further reductions (by the same emitters or others) or decrease the economic or political costs of those reductions. We will consider a number of possible pathways for these effects.

Pressure on exporters could provide one mechanism by which mitigation in some jurisdictions could broaden to include others. One mechanism involves industry's aversion to patchwork regulations. Lack of uniformity imposes significant costs on multinationals and producers of traded products. This can lead industry to support uniform regulation across jurisdictions, even if industry's ideal outcome would be to have no regulation at all. ${ }^{11}$ Sellers' desire for uniformity helped spark international action to protect the ozone layer, ${ }^{92}$ and a similar desire for uniformity may have contributed to the enactment of major federal environmental legislation in the 1970s. ${ }^{93}$

Lack of uniformity is a problem for the international transportation industry as well as for exporters. At this writing, the European Union is apparently attempting to exploit this fact to prompt international action on carbon emissions from airplanes. The EU has brought international flights under its trading system, requiring allowances or offsets for all emissions during a flight (both inside and outside European air space). ${ }^{94}$ The EU intimated, however, that it would back down if an international agreement on airline emissions were in store. ${ }^{95}$

The threat of border measures may also give exporting industries an incentive to support mitigation efforts in their own countries. Countries that commit themselves to carbon reductions may face significant leakage problems, which increase the prospect that they will turn to border measures. This

91 See J.R. DeShazo and Jody Freeman, Timing and Form of Federal Regulation: The Case of Climate Change, 155 U Pa L Rev 1499, 1506-10 (2006-07).

92 Kirsten H. Engel, State and Local Climate Change Initiatives: What is Motivating State and Local Governments to Address a Global Problem and What Does This Say About Federalism and Environmental Law, 38 Urban L 1015, 1026-27 (2006).

93 See E. Donald Elliott, Bruce A. Ackerman, and John C. Millian, Toward a Theory of Statutory Evolution: The Federalization of Environmental Lan, $1 \mathrm{~J} \mathrm{~L}$ Econ \& Org 313, 326-28 (1985).

94 See Joshua Meltzer, Climate Change and Trade-The EU Aviation Directive and the WTO, $15 \mathrm{~J}$ Intl Econ L 111, 114 (2012) (questioning whether the directive complies with WTO requirements).

95 See Daniel Pruzin, Official Says EU Will Not Suspend Inclusion of Airlines in Trading Plan as Talks Continue, 43 Envir Rptr (BNA) 742 (2012). 
prospect could lead to adoption of mitigation measures by exporting jurisdictions or by individual companies even without actual adoption of border measures.

Mitigation measures can also foster mitigation in other jurisdictions by reducing the cost of regulation or the risk that regulation will be unsuccessful. In this context, state governments in the US have been called laboratories of democracy. ${ }^{96}$ Early adopters of climate policies provide tests of policy effectiveness and the opportunity to learn from policy flaws. ${ }^{97}$ It is tempting to think that policies like emissions trading are well understood and not in need of such experimentation, but experience shows that designing a well-functioning cap-and-trade system is no easy matter. ${ }^{98}$ Diffusion of successful policies means that others can learn from these experiences, decreasing the costs of new policies and increasing their benefits. ${ }^{99}$ Organizations of local jurisdictions can expedite diffusion. ${ }^{100}$ Regional climate agreements, which have emerged within the US, ${ }^{101}$ can also lower policy costs and increase effectiveness by decreasing leakage and allowing coordination of policy instruments. ${ }^{102}$ Indeed, under some circumstances, linking the trading systems of multiple jurisdictions can lead, in a bottom-up process, to the creation of a global system. ${ }^{103}$ By demonstrating

96 Robert A. Schapiro, The Varieties of Federalism, in Schlager, Engel, and Rider, eds, Navigating Climate Change 35, 40-41 (cited in note 16).

97 See Benjamin K. Sovacool and Marilyn A. Brown, Scaling the Policy Response to Climate Cbange, 27 Poly \& Society 317, 319-20 (2009).

98 See Daniel A. Farber, Pollution Markets and Social Equity: Analyzing the Faimess of Cap and Trade, 39 Ecol L Q 1, 27 (2012).

99 Policy diffusion is a familiar, well-studied process. See Andrew Karch, Policy Diffusion and ClimateChange Poligy, in Schlanger, Engel, and Rider, eds, Navigating Climate Change 103, 103-17 (cited in note 16).

100 Judith Resnik, Joshua Civin, and Joseph Frueh, Changing the Climate: The Role of Translocal Organizations of Govermment Actors (TOGAs) in American Federalism(s), in Schlager, Engel, and Rider, eds, Navigating Climate Cbange 120, 120 (cited in note 16).

101 See Edella Schlager, Acting in Concert: State Efforts to Regionally Address Climate Cbange, in Schlager, Engel, and Rider, eds, Navigating Climate Change 144, 144-62 (cited in note 16).

102 For instance, the EU and Australia recently announced plans to link their carbon markets. See Murray Griffin and Stephen Gardner, EU, Australia to Link Carbon Schemes with First Phase Scheduled to Start in 2015, 35 Intl Envir Rptr (BNA) 834, 834 (2012).

103 See Jobst Heitzig, Bottom-Up Strategic Linking of Carbon Markets: Wbich Climate Coalitions Would Farsighted Players Form? 25 (Potsdam Institute For Climate Impact Research 2012). 
desire and competence to mitigate emissions, ${ }^{104}$ these efforts can also encourage broader agreements about climate mitigation. ${ }^{105}$

Even apart from the opportunity for policy improvement, early adopters can decrease the risks of new policies for other jurisdictions simply by providing evidence of costs and benefits. For instance, if California's cap-and-trade system is successful, that success should dissipate fears in some US quarters that climate mitigation would be economically disastrous.

Early-mitigating jurisdictions can also lower the cost of further reducing emissions by fostering technological innovation, which then decreases mitigation costs for others. Indeed, there may be policy advantages to local over largerscale adoption of technology policies, in part because localized efforts may be more diverse and may more effectively avoid the risks of picking the wrong technology. ${ }^{106}$ Local efforts may also take advantage of the potential for local geographic clusters to foster innovation because "spatial concentrations allow inventors to readily access knowledge that reduces the costs of research, development, and commercialization." 107 Improved technology can then lower the cost of mitigation in other jurisdictions.

Mitigation can also change the political dynamics facing policymakers. As Eric Biber has pointed out, mitigation policies can create a set of political supporters in the clean energy industry, thereby reducing the likelihood of backsliding:

[] $\mathrm{f}$ the new regulatory system requires significant economic investment, it can inspire the creation of new businesses, industrial systems, employment opportunities, etc. The individuals and corporations that benefit from this new economic investment can provide a political base of support for the new regulatory system, even in the absence of immediate environmental benefits. ... To the extent that climate change regulation is able to encourage the development of (for instance) new industries in renewable

104 The importance of signaling in this context is emphasized in Shi-Ling Hsu, $A$ Game-Theoretic Model of International Climate Change Negotiations, 19 NYU Envir L J 14, 55-60 (2011-12).

105 Remi Moncel, et al, Building the Climate Change Regime: Survey and Analysis of Approaches *37-38 (World Resources Institute Working Paper, 2011), online at http://pdf.wri.org/ working_papers/building_the_climate_change_regime.pdf (visited Oct 17, 2012).

106 See David E. Adelman and Kirsten H. Engel, Reorienting State Climate-Change Policies to Induce Technological Cbange, in Schlager, Engel, and Rider, eds, Navigating Climate Change, 163, 166 (cited in note 16).

107 Id at 167 . The possibility of obtaining long-term economic advantage provides an advantage to first movers. According to a report for the Council on Foreign Relations, "Past experience with high-technology industries strongly suggests that those countries that move first in developing new technologies and training an appropriately skilled workforce gain a substantial advantage in the global marketplace." George E. Pataki and Thomas J. Vilsack, Confronting Climate Change: $A$ Strategy for U.S. Foreign Poligy 20 (Council on Foreign Relations 2008). 
energy, this dynamic may play a role in maintaining support for the regulatory system. ${ }^{108}$

Indeed, firms that benefit from climate mitigation efforts have an incentive to press for further mitigation. Correspondingly, opponents of mitigation lose economic ground during the initial mitigation effort, making them less able to resist additional mitigation efforts. Thus, initial mitigation efforts may shift the political dynamics in favor of further mitigation.

This section has sketched some of the economic and political dynamics that could make cooperation contagious, as jurisdictions gain confidence in each other and their individual economics and political dynamics shift in favor of mitigation. There is certainly no guarantee that such dynamics will occur, but the possibility does provide support for subglobal action. It would be difficult to provide definitive proof about the relative strength of positive versus negative feedback effects in the adoption of local mitigation efforts and in international bargaining positions. To take one example, however, the failure of the US Congress to adopt climate regulation surely has not been helpful to international negotiations or encouraged more mitigation efforts in other countries.

Grounds for encouragement can be found in the extensive scholarly literature on policy diffusion. This literature confirms the existence of a tendency to imitate jurisdictions with seemingly successful programs. ${ }^{109}$ Moreover, countries often emulate similar countries even without evidence of policy success. ${ }^{10}$ Notably, diffusion is well documented in terms of environmental policies. $^{111}$

108 Eric Biber, Climate Change and Backlash, 17 NYU Envir L J 1295, 1340-41 (2008-09). The negative side of this phenomenon is that unsuccessful experiments may benefit from political lock-in. See William M. Shobe and Dallas Burtraw, Retbinking Environmental Federalism in a Warming World, Discussion Paper 12-04*26 (Resources for the Future 2012), online at http://www.rff.org/rff/Documents/RFF-DP-12-04.pdf (visited Oct 17, 2012). Biber argues in a more recent paper that this phenomenon helped protect California's AB 32 from an initiative challenge. See Eric Biber, Cultivating a Green Political Landscape: Lessons for Climate Change Policy from the Defeat of Califormia's Proposition 23, Vand L Rev *2 (forthcoming 2013), online at http://papers.ssrn.com/sol3/papers.cfm?abstract_id=2015774 (visited Oct 17, 2012).

109 See Chang Kil Lee and David Strang, The Intemational Diffusion of Public-Sector Downsizing: Network Emulation and Theory-Driven Leaming, 60 Intl Org 883, 905 (2006); Fabrizio Gilardi, Katharina Füglister, and Stephane Luyet, Learning and the Conditional Diffusion of Health-Care Cost-Sharing Policies in Europe *2-3 (Working Paper, 2010), online at http://www.fabriziogilardi.org/ resources/papers/refprice_july2010.pdf (visited Oct 17, 2012) (finding that reference pricing in health care "is more likely to be introduced when the experience of other countries seems to suggest that this policy helps constrain the rise of health expenditures").

110 Katerina Linos, Diffusion through Democray, 55 Amer J Pol Sci 678, 691 (2011).

111 Joanne Scott, From Brussels with Love: The Transatlantic Travels of European Law and the Chemistry of Regulatory Attraction, 57 Am J Comp L 897 (2009) (describing the migration of the EU's Regulation on Registration, Evaluation, Authorisation, and Restriction of Chemicals and its impact on 


\section{CONCLUSION}

As we have seen, there is legitimate concern that subglobal mitigation efforts could be undermined by leakage and might even reduce the impetus to global agreement. Although these possibilities are real, the evidence suggests that leakage is likely to be modest. We have also seen that subglobal action under plausible conditions would be contagious and make global cooperation more likely. Thus, there are good grounds for optimism about the utility of subglobal mitigation efforts.

Choosing a strategy depends not only on our expectations about the strategy but also on our view of alternatives. Even a risky strategy looks good if the alternatives are less promising. Thus, in considering the desirability of subglobal action, we must also consider the alternative to engaging in subglobal action pending global agreement. That alternative is simply to make no efforts at mitigation until a binding global agreement is in place. It is distinctly unpromising.

The strategy of waiting for a global agreement poses a host of risks of its own. Because of the absence of any mitigation efforts, the stock of carbon in the atmosphere will have grown, requiring sharper emission reductions and more expensive efforts at mitigation. The added expense would make forming an agreement more difficult. In addition, mitigation would then have to proceed with technologies that had never been used at scale and with untested regulatory schemes, increasing the likelihood of failure. Effective regulatory or taxation schemes require experience and fine-tuning-learning by doing - in order to be completely successful. It would be risky to make a global agreement without any previous practice with the requisite mitigation strategies.

Pending a global agreement, and in the absence of any subglobal mitigation efforts, the fossil fuel industries in each country would have grown without restraint, with more long-term infrastructure that locks in these forms of energy. And finally, since none of the countries involved would have had any history of mitigation efforts, there would be no track record to establish a sense of mutual confidence that the agreement will actually be implemented. ${ }^{112}$ This is not an

reforms in the US); Per-Olof Busch, Helge Jörgens, and Kerstin Tews, The Global Diffusion of Regulatory Instruments: The Making of a New Intermational Environmental Regime, 598 ANNALS of the Am Acad of Pol and Soc Sci 146 (2005) (describing the environmental reforms of the 1990s as an example of voluntary emulation); David John Frank, Ann Hironaka, and Evan Schofer, The Nation-State and the Natural Environment over the Twentieth Century, 65 Am Soc Rev 96 (2000).

112 As Shi-Ling Hsu points out, mitigation measures "in the real world of international relations ... must signal a turn, political or social, representing a commitment to some different path" and thereby have "the effect of irrevocably committing some resources ... and signaling the possibility of reciprocity should another party make a similar or greater commitment." Hsu, 
appealing scenario. Perhaps eschewing interim measures made a certain amount of sense when a global agreement seemed more imminent, but it would be hard to find anyone today who expects such an agreement in the near future.

When dealing with an unprecedented problem like global climate change, we can never be certain of the best policy response. On balance, however, it seems wiser for jurisdictions to take the chance of beginning mitigation without waiting for a global agreement. At a minimum, these efforts communicate a willingness to negotiate; probably they also reduce total global emissions and slow climate change. With any luck, they create a feedback effect that will lead toward global emissions reductions. The alternative strategy of waiting for a global agreement holds little promise. Subglobal action is not a sure thing, but it is the best bet for bridging the time until a global regime emerges.

19 NYU Envir L Rev at 56 (cited in note 104). Conversely, heavy investment in coal-fired power plants signals a "prioritization of economic development over climate concerns." Id. 


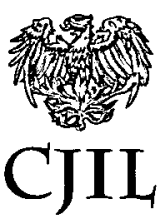

